\title{
Figural Creativity, Creative Potential, and Personality among Taiwanese Fashion Design Undergraduates
}

\author{
Kuan-Chen Tsai \\ School of Design, Asia University \\ 500, Lioufeng Rd., Wufeng, Taichung 41354, Taiwan \\ E-mail: tsaikuanchen@asia.edu.tw
}

Received: August 25, 2018 Accepted: October 23, 2018 Published: December 17, 2018

doi:10.5296/gjes.v4i2.13546

URL: https://doi.org/10.5296/gjes.v4i2.13546

\begin{abstract}
For modern visual artists and graphic designers, creativity is the sine qua non, and it should be equally important to fashion designers. The main objective of this study was to investigate the relationships among figural creativity, creative potential, and personality in a sample of Taiwanese fashion design undergraduates. Convenient sampling was used. A sample of 90 first-year fashion design undergraduate students (73 women and 17 men) at Asia University in Taiwan, was recruited from the Foundation of Design, which is the foundational fashion design course, to participant in this study. This study's results suggest that figural creativity is not related to creative potential or to personality. However, we suggest that using alternative or additional instruments to measure creative potential and/or include additional relevant variables might build on these findings and increase our understanding of the relationships among figural creativity, creative potential, and personality.
\end{abstract}

Keywords: Figural creativity, Creative potential, Personality, Fashion design, Taiwan 


\section{Introduction}

Creativity tends to characterize distinguished people in the sciences, arts, politics, and business. As such, it could be considered a highly desirable quality and an important tool for coping with life's stresses and problems (Hennessey \& Amabile, 2010). For modern visual artists and graphic designers, creativity is essential (Smith, 2014; Yang \& Hsu, 2017), and it should be equally important to fashion designers (Lilia, 2017).

The Torrance Tests of Creative Thinking (TTCT), which assess verbal and figural creativity, are probably the most frequently applied tests of creativity (Kim, 2006a; Torrance, 1990). Previous studies on figural creativity often employed the figural portion of the TTCT (TTCT-Figural) to measure figural creativity because the TTCT is widely accepted as an indicator of individual creativity (e.g., Oncu, 2016; Rabanos \& Torres, 2012; Travis \& Lagrosen, 2014). The TTCT-Figural comprises three activities: picture construction, picture completion, and repeated figures composed of lines or circles. It assesses five aspects of creativity: (1) fluency and quantity of relevant ideas; (2) originality and quantity of statistically infrequent ideas; (3) elaboration and quantity of added ideas; (4) abstractness of titles and the extent beyond labeling; and (5) resistance to premature closure and the extent of psychological openness.

Kim (2006b) compared the Kirton Adaption-Innovation Inventory (Kirton, 1976) to the figural portion of the TTCT using confirmatory factor analysis. He found that the measures of fluency, originality, and resistance to closure in the TTCT related to Kirton's "Innovator" style, and the measures of elaboration, abstractness of titles, and creative closure in the TTCT related to Kirton's "Adaptor style.”

Although the TTCT is popular among students of creativity, several scholars have challenged its legitimacy and pointed out its deficiency as possibly assessing individual creative performance incorrectly (Hennessey \& Amabile, 1999; Kaufman \& Baer, 2012). These scholars have argued that actual creative performance should be the gold standard used to assess individual creativity, and they tend to use method that examines creative products. A frequently used method is Amabile (1996) Consensual Assessment Technique (CAT), with which experts in relevant fields assess creative products, such as poems, collages, or short stories.

According to Batey and Furnham's (2006) and James and Asmus's (2001) critical review of the research on personality and creativity, it is challenging to develop a comprehensive list of personality variables across the various domains of creative endeavors. However, although they found that certain personality traits were more important for certain domains than others, one group of characteristics somewhat consistently related to creativity, including self-esteem, independence, introversion, perseverance, social poise, tolerance of ambiguity, willingness to take risks, behavioral flexibility, and emotional variability.

The Big Five Personality Traits in the Big Five Personality Theory (openness to experience, extraversion, neuroticism, agreeableness, and conscientiousness) are the most commonly used traits in personality research (Goldberg, 1999). Among them, openness to experience is 
the most closely related to creativity (Feist, 1998). Extraversion also is important to creativity. Sung and Choi (2009) found that extraversion might be the most significant predictor of individual creative performance and, empirically extraversion and openness to experience significantly influenced individual creativity. In addition, in Tsai's (2017) study, the results show that creative problem solving and personality was correlated.

This study aimed to gain knowledge about the figural creativity and creative potential of fashion design undergraduates. Through that knowledge, we hope to determine the extent to which we should promote creativity in these students.

\section{Purpose and Research Questions}

The main objective of this study was to investigate the relationships among figural creativity, creative potential, and personality in a sample of Taiwanese fashion design undergraduates. Fashion illustration is an important skill for fashion designers because fashion design sketches might be the maps used in the subsequent stages of producing apparel. In addition, creativity could be an asset for fashion designers who design their personal unique apparel. Therefore, the current study focused on understanding creative performance among student fashion designers. Based on preceding discussion, personality is also important factor to affect creativity. As is clear from the previous discussion, personality is important to creative expression, and this study considered personality traits when assessing the subjects' creative performance. The following three questions were developed to address the study's objectives.

1) What is the relationship among the figural creativity, creative potential, and personality of student fashion designers?

2) Do personality traits predict figural creativity or creative potential?

3) Does creative potential predict figural creativity net of the effects of personality traits and vice versa?

\section{Method}

\subsection{Participants}

Convenient sampling was used in this study. A sample of 90 first-year fashion design undergraduate students at Asia University in Taiwan was recruited from the Foundation of Design, which is the foundational fashion design course, to participant in this study. About $81 \%$ (73) of the sample was female and $19 \%$ (17) of the sample was male. Mean age was 18.6 years old $(S D=1.85)$.

\subsection{Participants Instruments and Measurement}

\subsubsection{Figural Creativity}

Figural creativity was assessed with Clark's Drawing Abilities Test (CDAT; Clark \& Zimmerman, 2004). The CDAT has been used on more than 5000 elementary-, middle- and high- school students in the US and other countries, and it is a reliable and valid instrument (Chan, 2009; Chan \& Zhao, 2010). The CDAT comprises four tasks: (a) drawing an 
interesting house as if you were viewing it from across the street; (b) drawing a person running very fast; (c) drawing yourself playing with your friends in a playground; and (d) drawing a fantasy picture using your imagination. The scores on these tasks have four criteria: originality, expressiveness, creative solutions, and drawing skills. Because of this study's goals and research questions, we used task (d).

The scoring method on CDAT followed Chan's (2009) use of Amabile's (1996) CAT. Five art educators were invited to serve as a panel of experts. They were provided with scoring sheets and instructed to assign global ratings on figural creativity, drawing skill and aesthetics for each participant on a scale, ranging from $1=$ very low to $5=$ very high. Inter-rater reliability was assessed using Cronbach's alpha, which was .882 on figural creativity, .901 on drawing skill, and .911 on aesthetics. Index scores were created by computing the mean of the figural creativity, drawing skill, and aesthetics scores assigned by the five experts.

\subsubsection{Creative Potential}

The Chinese version of the Runco Ideational Behavior Scale (RIBS; Tsai, 2015) was developed by Runco, Plucker, and Lim (2000-2001) to measure individual ideational behavior as the combination of ideas to generate them. Plucker, Runco, and Lim (2006) argued that the main reason for developing the RIBS was to create a criterion of creative potential as a possible alternative measure of divergent thinking. The 23 items in the RIBS measure actual overt behaviors related to ideation. According to Runco et al. (2000-2001) and Tsai (2015), the RIBS is a reliable instrument, although its construct validity is somewhat ambiguous. Both studies found that two factors in the RIBS, but, because of lack of theoretical justification, Runco et al. (2000-2001) suggested that a one-factor structure should be used to interpret RIBS results.

\subsubsection{Personality}

The 10-Item Personality Inventory (TIPI; Gosling, Rentfrow, \& Swann, 2003), was used to measure the participants' personality traits. The TIPI's 10 items are structured into five domains of two items each one of which is positive and the other of which is negative. The participants were asked to assess their personalities on a 7-point Likert-type scale ranging where 1 = disagree strongly to 7 = agree strongly.

Gosling et al. (2003) reported on the TIPI's reliability and found Cronbach's alpha of 0.68 on extraversion, 0.40 on agreeableness, 0.50 on conscientiousness, 0.73 on emotional stability, and 0.45 on openness to experience. These relatively low alpha values likely relate to the fact that each factor has only two items. The same authors reported adequate test-retest reliability ranging from 0.62 to 0.77 , over a six-week period, and validated their 10 -item inventory using the 44-item Big- Five Instrument (John \& Srivastava, 1999) and using the NEO-PI-R (Costa \& McCrae, 1992). The results indicated that the TIPI had adequate convergent validity.

\subsection{Procedure}

Participation in this study was a course requirement. First, the study and its objective were 
explained to the participants. Then, they were asked to provide personal information on age and gender. The tests were then administered. The participants were asked to draw the first task with a pencil during a 20-minute period so that their figural creativity could be assessed. After the drawing task, they were provided with 10 minutes to complete the self-evaluation of creative potential and the personality tests. The entire process was completed in 35 minutes.

\section{Results}

\subsection{Correlation Analysis}

Table 1 shows means, standard deviations and correlation coefficients on the five personality traits, RIBS, figural creativity, skill, and aesthetics. The Pearson correlations indicate that figural creativity, skill, and aesthetics positively and significantly correlated with each other, ranging from $r=.886$ to $r=.906$. However, figural creativity did not significantly correlate with creative potential or personality. Creative potential significantly correlated only with extraversion $(r=.316)$ and openness to experience $(r=.469)$. Among the five personality variables, agreeableness and emotional stability were positively correlated $(r=.369)$, and openness to experience positively correlated with extraversion $(r=.352)$ and conscientiousness $(r=.288)$.

Table 1. Means, standard deviations, and correlation among nine variables

\begin{tabular}{|l|c|c|c|c|c|c|c|c|c|c|c|}
\hline \multicolumn{1}{|c|}{ Variable } & $M$ & $S D$ & 1 & 2 & 3 & 4 & 5 & 6 & 7 & 8 & 9 \\
\hline 1.Figural creativity & 3.78 & .85 & -- & & & & & & & & \\
\hline 2.Skill & 3.76 & .83 & $.904^{* *}$ & -- & & & & & & & \\
\hline 3.Aesthetics & 3.67 & .86 & $.886^{* *}$ & $.906^{* *}$ & -- & & & & & & \\
\hline 4.RIBS & 3.23 & .47 & .099 & .160 & .116 & -- & & & & & \\
\hline 5.Extraversion & 4.32 & 1.31 & .164 & .142 & .142 & $.316^{* *}$ & -- & & & & \\
\hline 6.Agreeableness & 5.17 & .94 & .001 & .004 & .094 & -.173 & .012 & -- & & & \\
\hline 7.Conscientiousness & 4.98 & .99 & -.170 & -.174 & -.107 & .135 & -.009 & .070 & -- & & \\
\hline $\begin{array}{l}\text { 8.Emotional } \\
\text { stability }\end{array}$ & 4.34 & 1.22 & .032 & -.045 & .001 & -.060 & -.173 & $.369 * *$ & .197 & -- & \\
\hline $\begin{array}{l}\text { 9.Openness } \\
\text { experience }\end{array}$ & 5.26 & 1.04 & .115 & .122 & .073 & $.469 * *$ & $.352^{* *}$ & -.009 & $.288^{* *}$ & .125 & - \\
\hline ** $p<.01$. & & & & & & & & & & & \\
\hline
\end{tabular}

\subsection{Prediction Analysis}

Multiple correlation regression analysis was used to address the research question regarding the relationships of the personality traits to figural creativity. The results found that $F(5,84)$ $=1.39, p=.24$ and, as Table 2 and Table 3 indicates, none of the measures of personality were statistically significant predictors of figural creativity. The analysis of the effects of personality on creative potential found that $F(5,84)=6.44, p<.001$, but openness to 


\section{Ml Macrothink}

Global Journal of Educational Studies

ISSN 2377-3936

2018, Vol. 4, No. 2

experience was the only statistically significant predictor in the model, $t=3.76, p<.001, \beta$ $=.40, R^{2}=.277$.

To obtain a complete analysis of the effects of other factors that influence figural creativity, figural creativity was regressed on eight variables (five personality variables, creative potential, skill, and aesthetics). The results found that $F(8,81)=54.68, p<.001$, and Table 4 shows that three variables were statistically significant predictors in the model $\left(R^{2}=.84\right)$ : emotional stability $(t=2.01, p=.048, \beta=.10)$, skill $(t=5.93, p<.001, \beta=.65)$, and aesthetics $(t=2.58, p=.012, \beta=.28)$.

Table 2. Standard regression analysis summary for personality predicting figural creativity

\begin{tabular}{|l|c|c|c|c|c|}
\hline \multicolumn{1}{|c|}{ Variable } & $\mathrm{B}$ & SE B & $\beta$ & $t$ & $p$ \\
\hline Extraversion & .09 & .08 & .14 & 1.17 & .25 \\
\hline Agreeableness & -.02 & .10 & -.02 & -.16 & .87 \\
\hline Conscientiousness & -.19 & .10 & -.22 & -1.97 & .05 \\
\hline Emotional stability & .06 & .08 & .09 & .76 & .45 \\
\hline Openness to experience & .10 & .10 & .12 & .99 & .32 \\
\hline R square =.076 & \multicolumn{5}{|l}{} \\
\hline
\end{tabular}

Table 3. Standard regression analysis summary for personality predicting creative potential

\begin{tabular}{|l|c|c|c|c|c|}
\hline \multicolumn{1}{|c|}{ Variable } & $\mathrm{B}$ & SE B & $\beta$ & $t$ & $p$ \\
\hline Extraversion & .06 & .04 & .17 & 1.68 & .096 \\
\hline Agreeableness & -.08 & .05 & -.16 & -1.63 & .108 \\
\hline Conscientiousness & .02 & .05 & .04 & .39 & .699 \\
\hline Emotional stability & -.01 & .04 & -.03 & -.26 & .796 \\
\hline Openness to experience & .18 & .05 & .40 & 3.76 & .000 \\
\hline R square $=.277$
\end{tabular}

Table 4. Standard regression analysis summary for eight variables predicting figural creativity

\begin{tabular}{|l|c|c|c|c|c|}
\hline \multicolumn{1}{|c|}{ Variable } & $\mathrm{B}$ & SE B & $\beta$ & $t$ & $p$ \\
\hline Extraversion & .04 & .03 & .06 & 1.28 & .204 \\
\hline Agreeableness & -.07 & .05 & -.08 & -1.52 & .132 \\
\hline Conscientiousness & -.03 & .04 & -.04 & -.79 & .431 \\
\hline Emotional stability & .07 & .04 & .10 & 2.01 & .048 \\
\hline Openness to experience & .02 & .05 & .02 & .44 & .663 \\
\hline RIBS & -.13 & .09 & -.07 & -1.35 & .182 \\
\hline Skill & .67 & .11 & .65 & 5.93 & .000 \\
\hline Aesthetics & .28 & .12 & .28 & 2.58 & .012 \\
\hline R square $=.84$ & \multicolumn{5}{l}{} \\
\hline
\end{tabular}




\section{Discussion}

Several limitations should be considered when interpreting these findings. First, the analysis used the RIBS to measure ideational behavior to assess creative potential. Although divergent thinking tests like the RIBS are popular in the creativity literature, several concerns exist regarding the scoring system (Silvia et al., 2008). Therefore, future studies should consider using other creative potential assessments or using more than one such measure. Another salient limitation is that the sample was recruited from one institution and the participants are all of one ethnic background. However, cross-cultural studies seem to a promising option for validating the current findings. Finally, our study was correlational in nature. In terms of research design, conducting an experimental study could provide robust findings on the relationships among these three variables.

The main objective of the current study was to identify relationships among figural creativity, creative potential, and personality in a sample of fashion design college students. According to zero-order correlations, we found that figural creativity correlated with neither creative potential nor personality, and creative potential only correlated with extraversion $(r=.316)$ and openness to experience $(r=.469)$. These findings were unexpected, but one explanation for them is that although the RIBS was designed to measure creative potential, the RIBS framework is theoretically grounded in divergent thinking, not creativity. Moreover, because this study used the participants' work products to assess their figural creative performance by having five experts rate their output, the two instruments were, in essence, from different perspectives on creativity.

Regarding personality, the results on extraversion and openness to experience positively correlated with creative potential, which supports previous studies on creativity. In fact, openness to experience is generally considered the personality trait most important to creativity (Hennessey \& Amabile, 2010). However, none of the measures of personality correlated with figural creativity in our data. This finding seems to contradict previous studies, but, to the best of our knowledge, studies on the relationship of personality to figural creativity are scarce. Consequently, it would be useful to conduct more studies on this relationship.

The second research question of the current study was " Do personality traits predict figural creativity or creative potential? To address this question, we estimated two multiple standard regression models. The results found that personality was not significantly influential to variation in figural creativity in our sample, but personality was significantly important to variation in creative potential. Specifically, openness to experience $(\beta=.40)$ significantly predicted creative potential. As previously discussed, more research is needed to obtain a clear picture of the relative predictive power of these variables on figural creativity.

The final research question of this study was "Does creative potential predict figural creativity net of the effects of personality traits and vice versa?" In a multiple regression estimation including all eight variables, we found that emotional stability $(\beta=.10)$, skill ( $\beta$ $=.65$ ), and aesthetics $(\beta=.28)$ were statistically significant (controlling for the effects of the personality variables), among which skill was the strongest predictor of figural creativity ( $\beta$ 
$=.65, p<.001)$. This finding means that drawing skill positively influenced figural creativity. It is clear that, to express creativity, knowledge and skill are needed. The creativity literature indicates that to achieve outstanding breakthroughs and creative achievements, individuals need at least 10 years of study in the field (Simonton, 2006). Moreover, in this model, only one personality trait (emotional stability) was a significant factor. When we further examined these relationships, the statistical significance was marginal $(p=.048)$. We speculated that unobserved variables might have influenced the results. We suggest that future studies include relevant variables to clarify these possible relationships.

\section{Conclusion}

This study's results suggest that figural creativity is not related to creative potential or to personality. However, we suggest that using alternative or additional instruments to measure creative potential and/or include additional relevant variables might build on these findings and increase our understanding of the relationships among figural creativity, creative potential, and personality. Despite its weaknesses, this study is a first step toward understanding variation in the creative performance of fashion design students. Importantly, the next steps for educators should be attempts to facilitate creativity among students in classroom settings. By maximizing students' creativity in the classroom, their fashion design projects (apparel or accessory design) and their future career paths might be substantially supported.

\section{References}

Amabile, T. M. (1996). Creativity in context. Boulder, CO: Westview.

Batey, M., \& Furnham, A. (2006). Creativity, intelligence, and personality: A critical review of the scattered literature. Genetic, Social \& General Psychology Monographs, 132(4), 355-429. https://doi.org/10.3200/MONO.132.4.355-430

Chan, D. W. (2009). Drawing abilities of Chinese gifted students in Hong Kong: Prediction of expert judgments by self-report responses and spatial tests. Roeper Review, 31(3), 185-194. https://doi.org/10.1080/02783190902994084

Chan, D. W., \& Zhao, Y. (2010). The relationship between drawing skill and artistic creativity: Do age and artistic involvement make a difference? Creativity Research Journal, 22(1), 27-36. https://doi.org/10.1080/10400410903579528

Clark, G., \& Zimmerman, E. (2004). Teaching talented art students: Principles and practices. New York: Teachers College, Columbia University.

Costa, P. T., Jr., \& McCrae, R. R. (1992). Revised NEO Personality Inventory (NEO-PI-R) and NEO Five-Factor Inventory (NEO-FFI) professional manual. Odessa, FL: Psychological Assessment Resources, Inc.

Feist, G. J. (1998). A meta-analysis of personality in scientific and artistic creativity. Personality and Social Psychology Review, 2(4), 290-309. https://doi.org/10.1207/s15327957pspr0204_5

Goldberg, L. R. (1999). A broad-bandwidth, public-domain, personality inventory measuring the lower-level facets of several Five-Factor models. Personality Psychology in Europe, 7(1), 
7-28.

Gosling, S. D., Rentfrow, P. J., \& Swann, W. B. (2003). A very brief measure of the Big-Five personality domains. Journal of Research in Personality, 37, 504-528. https://doi.org/10.1016/S0092-6566(03)00046-1

Hennessey, B. A., \& Amabile, T. M. (1999). Consensual assessment. In M. A. Runco, \& S. R. Pritzker (Eds.), Encyclopedia of creativity (pp. 347-359). San Diego, CA: Academic Press.

Hennessey, B. A., \& Amabile, T. M. (2010). Creativity. Annual Review of Psychology, 61(1), 569-598. https://doi.org/10.1146/annurev.psych.093008.100416

James, K., \& Asmus, C. (2001). Personality, cognitive skills, and creativity in different life domains. Creativity Research Journal, 13(2), 149-159. https://doi.org/10.1207/S15326934CRJ1302_3

John, O. P., \& Srivastava, S. (1999). The Big Five trait taxonomy: History, measurement, and the theoretical perspectives. In L. A. Pervin, \& O. P. John (Eds.), Handbook of personality: Theory and research (pp. 102-138). New York: Guilford Press.

Kaufman, J. C., \& Baer, J. (2012). Beyond new and appropriate: Who decides what is creative? Creativity Research Journal, 24(1), 83-91. https://doi.org/10.1080/10400419.2012.649237

Kim, K. H. (2006a). Can we trust creativity tests? A review of the Torrance Tests of Creative Thinking (TTCT). Creativity Research Journal, 18(1), 3-14. https://doi.org/10.1207/s15326934crj1801_2

Kim, K. H. (2006b). Is creativity unidimensional or multidimensionak? Analysis of the Torrance Tests of Creative Thinking? Creativity Research Journal, 18(3), 251-259. https://doi.org/10.1207/s15326934crj1803_2

Kirton, M. J. (1976). Adaptors and innovators: A description and measure. Journal of Applied Psychology, 61(1), 622-629. https://doi.org/10.1037/0021-9010.61.5.622

Lilia, G.-L. (2017). The experiential learning impact of international and domestic study tours: Class excursions that are more than field trips. International Journal of Teaching and Learning in Higher Education, 29, 129-144.

Oncu, E. C. (2016). Improved creative thinkers in a classroom: A model of activity based tasks for improving university students' creative thinking abilities. Education Research and Reviews, 11(8), 517-522. https://doi.org/10.5897/ERR2015.2262

Plucker, J. A., Runco, M. A., \& Lim, W. (2006). Predicting ideational behavior from divergent thinking and discretionary time on task. Creativity Research Journal, 18(1), 55-63. https://doi.org/10.1207/s15326934crj1801_7

Rabanos, N. L., \& Torres, P. A. (2012). Effects of a program for developing creative thinking skills. Electronic Journal of Research in Educational Psychology, 10(3), 1139-1158.

Runco, M. A., Plucker, J. A., \& Lim, W. (2000-2001). Development and psychometric integrity of a measure of ideational behavior. Creativity Research Journal, 13(3\&4), 393-400.

Silvia, P. J., Winterstein, B. P., Willse, J. T., Barona, C. M., Cram, J. T., Hess, K. I., Martinez, J. L., \& Richard, C. A. (2008). Assessing creativity with divergent thinking tasks: Exploring the reliability and validity of new subjective scoring methods. Psychology of Aesthetics, 


\section{Macrothink}

Global Journal of Educational Studies

ISSN 2377-3936

2018, Vol. 4, No. 2

Creativity, and the Arts, 2(2), 68-85. https://doi.org/10.1037/1931-3896.2.2.68

Simonton, D. K. (2006). Creative genius, knowledge, and reason: The lives and works of eminent creators. In J. C. Kaufman \& J. Baer (eds.), Creativity and reason in cognitive development (pp. 43-59). New York, NY: Cambridge University Press. https://doi.org/10.1017/CBO9780511606915.004

Smith, J. K. (2014). Art as mirror: Creativity and communication in aesthetics. Psychology of Aesthetics, Creativity, and the Arts, 8(1), 110-118. https://doi.org/10.1037/a0035691

Sung, S. Y., \& Choi, J. N. (2009). Do big five personality factors affect individual creativity? The moderating role of extrinsic motivation. Social Behavior and Personality: An International Journal, 37(7), 941-956. https://doi.org/10.2224/sbp.2009.37.7.941

Torrance, E. P. (1990). The Torrance tests of creative thinking norms-technical manual figural (streamlined) forms $A \&$ \& . Bensenville, IL: Scholastic Testing Service, Inc.

Travis, F., \& Lagrosen, Y. (2014). Creativity and brain-functioning in product development engineers: A canonical correlation analysis. Creativity Research Journal, 26(2), 239-243. https://doi.org/10.1080/10400419.2014.901096

Tsai, K. C. (2015). Assessing a Chinese version of the Runco Ideational Behavior Scale (RIBS). Social Behavior and Personality: An International Journal, 43(7), 1111-1122. https://doi.org/10.2224/sbp.2015.43.7.1111

Tsai, K. C. (2017). Creative problem solving styles and personality types in Macau college students: A canonical correlation analysis. Global Journal of Educational Studies, 3(1), 1-9. https://doi.org/10.5296/gjes.v3i1.10780

Yang, C. M. \& Hsu, T. F. (2017). New perspective on visual communication design education: An empirical study of applying narrative theory to graphic design courses. International Journal of Higher Education, 6(2), 188-198. https://doi.org/10.5430/ijhe.v6n2p188

\section{Copyright Disclaimer}

Copyright for this article is retained by the author(s), with first publication rights granted to the journal.

This is an open-access article distributed under the terms and conditions of the Creative Commons Attribution license (http://creativecommons.org/licenses/by/3.0/). 